\title{
Researching Oral Production Skills of Young Learners
}

\author{
Magdalena SZPotowiCZ ${ }^{1}$
}

$\approx$ This chapter focuses on the development of young learners' ability to communicate in a foreign language. An empirical study was carried out to determine whether, after four years of learning English as a compulsory school subject, children are ready to engage in oral interaction in a semicontrolled task and produce answers and questions in English. A convenience sample of ten-year-old children was selected from 180 participants in $\mathrm{ELLiE}^{2}$ in Poland. Six learners from one class of each of seven schools were selected on the basis of teachers' reports to ensure equal proportions of learners with low, medium and high ability. Schools were chosen to represent different socio-economic milieux. The results of the Year Four oral test (an interactive task) showed that almost all the participating children could respond to questions but only half were able to ask questions. Considering generally positive attitudes to speaking activities, the results suggest that ten-year-old children are already developing their interactive skills and could benefit from more interaction-focused classroom activities. Further experimental classroom-based studies are necessary to gain better insight into potential oral achievements in this age group. The results are discussed in the context of national curriculum requirements, drawing on the Common European Framework of Reference level descriptors.

Keywords: instructed contexts, oral production, speaking tasks, task achievement, young learners of English

$1 \quad$ University of Warsaw, Poland m.szpotowicz@uw.edu.pl

2 ELLiE Project (Early Language Learning in Europe) - a longitudinal, multinational research project carried out in seven European countries in 2007-2010 (www.ellieresearch.eu; Enever, 2011) 


\section{Raziskovanje spretnosti govornega izražanja mlajših učencev}

Magdalena Szpotowicz

$\propto \quad$ V prispevku je predstavljen razvoj govorne zmožnosti mlajših učencev $\mathrm{v}$ tujem jeziku. Opravljena je bila empirična raziskava, s katero so poskušali ugotoviti, ali so po štirih letih učenja angleščine kot obveznega predmeta $\mathrm{v}$ šoli učenci sposobni govorne interakcije $\mathrm{v}$ delno kontroliranih situacijah/nalogah; ali znajo postavljati vprašanja in odgovarjati $\mathrm{v}$ angleščini. Vzorec so sestavljali naključno izbrani desetletni učenci, medtem ko je v študiji $\mathrm{ELLiE}^{3}$ na Poljskem sodelovalo 180 učencev. Na osnovi učiteljevih poročil, s čimer so želeli zagotoviti enak odsototek učencev z nižjimi, srednjimi in z višjimi sposobnostmi, je bilo na sedmih šolah v enem razredu izbranih šest učencev. Šole so bile izbrane iz različnih socialno-ekonomskih področij. Izsledki govornega preizkusa četrtošolcev (preizkus sporazumevanja) so pokazali, da so bili skoraj vsi vključeni učenci sposobni odgovarjati na vprašanja, medtem ko jih je polovica znala postavljati tudi vprašanja. Ob upoštevanju splošne naklonjenosti učencev govornim aktivnostim in na osnovi rezultatov lahko ugotovimo, da desetletni učenci že razvijajo sporazumevalno zmožnost in da bi lahko z večjim številom razrednih aktivnosti, ki bi bile usmerjene $\mathrm{v}$ sporazumevanje, še več pridobili. Da bi pridobili boljši vpogled v potencialne govorne dosežke, ki bi jih učenci lahko dosegli pri tej starosti, bi bile potrebne nadaljnje eksperimentalne raziskave $\mathrm{v}$ razredu. Izsledki so analizirani glede na nacionalne kurikularne zahteve, s sklicevanjem na ravni opisnikov Skupnega evropskega jezikovnega okvira.

Ključne besede: pouk, govorno tvorjenje, govorne naloge, izpolnitev naloge, mlajši učenci angleščine

3 ELLiE Project (Zgodnje učenje jezika v Evropi) - longitudinalni, mednarodni raziskovalni projekt, ki se je odvijal v več državah Evrope v obdobju 2007-2010 (www.ellieresearch.eu; Enever 2011) 


\section{Introduction}

\section{Communicative language ability}

Communication in a foreign language is a challenge for young learners for two main reasons. First, their lexical and grammatical knowledge is still growing owing to limited target language exposure in or outside school. Second, children between 5 to 10 years of age are still developing awareness of what other people understand from what they say, and are learning how to ask for clarification (Cameron, 2001, p. 52). However, irrespective of learners' ages, communicative ability is the main goal of foreign language education. Parents and foreign language curricula require the demonstration of young language learners' productive skills.

Bachman and Palmer (2010) proposed a framework of two components for language ability: language competence, termed 'language knowledge', and strategic competence, which is described as:

a set of metacognitive strategies that manage the ways in which language users utilize their different attributes (e.g. language knowledge, topical knowledge, affective schemata) to interact with the characteristics of the language use situation (ibid., p. 44).

In the framework, language knowledge is described as a domain of information' available for language users and consisting of organizational knowledge (divided into the grammatical and textual) and pragmatic knowledge (divided into functional and sociolinguistic). Although the model of language knowledge contains many areas, language research and assessment often focuses on one aspect only, e.g. knowledge of vocabulary (ibid.). Young learners' initial language knowledge is restricted to individual lexical items and may be assumed to be the only language knowledge available. Lexical knowledge may represent all the language knowledge they possess at a certain point of language development.

Strategic competence is defined as 'higher-order metacognitive strategies that provide a management function in language use, as well as in other cognitive activities' (ibid., p. 48). Although the authors identify three general areas in which metacognitive strategies operate (goal setting, appraising and planning), they associate the use of these strategies with all cognitive activity, not only language use. Bachman and Palmer (ibid.) also stressed that using language involves topical knowledge, affective schemata and the above areas of language knowledge. 'What makes language use possible is the integration of 
these attributes as language users create and interpret discourse in situationally appropriate ways' (ibid., p. 49). In the context of teaching and testing young learners, it is relevant to relate their communicative language to the above model. Age-appropriate interactive tasks designed to elicit language from young learners can provide evidence of emerging language ability.

\section{Speech elicitation tasks}

A language elicitation task for children should be closely linked to their classroom experience. For children, 'real' and 'authentic' language use will be classroom language, as they have limited contact with the foreign language outside the classroom. Nevertheless, not every classroom activity can be defined as a task. Cameron (2001, p. 31) defined key features of classroom tasks for children learning a foreign language: they need to (a) have some coherence and unity for the learners, for example through topic, type of activity or their outcome, (b) have meaning and purpose, (c) have a beginning and end, and (d) involve learners actively.

Designing a developmentally appropriate task that is meaningful and elicits language that young learners are able and ready to produce is demanding. McKay (2006, pp. 186-187) discussed the appropriateness and usefulness of oral language tasks by emphasizing a few vital features. They are more useful if some visual support, such as pictures, objects or body language is provided. Some introductory activity should be offered to help children 'tune' into the topic and the language to be used. Tasks that are structured and supported closely by the adult are more accessible than those requiring sophisticated language strategies or turn-taking in group discussion.

Among the tasks eliciting oral production, McKay (ibid., p. 204) placed simple question-and-answer tasks, oral interviews, mini-dialogues and roleplays and oral information gap tasks. Oral information gap tasks require children to interact and use language to complete the task, e.g. one child tells the other what to draw, match or highlight. They can be used as games in the classroom and also for assessment purposes. Selected children's performance can be audio-recorded and analysed later by the teacher.

\section{Teaching children to speak}

The first stages of teaching children to speak introduce simple dialogues and require answering questions; all taught as 'unanalysed chunks' of language. These are reinforced through chants and rhymes, as well as question and answer routines with the teacher (Slattery \& Willis, 2001; Brewster \& Ellis, 2002; Pinter, 2006). 
Teaching speaking at the onset of early school years presents a double challenge. First, oral skills develop when a child's lexicon is slowly expanding in classroom conditions and require extensive reinforcement. Second, interactive ability and awareness of the interlocutor is still developing in the mother tongue. Children slowly develop the ability to negotiate meaning and are more concerned with their own understanding than with the needs of their listeners. This means that interactive tasks require careful selection and preparation (Pinter, 2006, pp. 56-59). From a teacher's perspective and the needs to expand children's lexical knowledge, finding the right time to introduce more interactive activities and exploit learners' interest in participating in meaningful communicative tasks presents an additional challenge.

In the study described by Muñoz (2007, pp. 245-246), a group of 88 experienced foreign language teachers were asked to rank activities presented in a questionnaire according to their suitability for teaching different learner groups (pre-primary, primary and secondary) according to the four language skills. Activities ranked by over $50 \%$ of the teachers as 'very suitable' for practicing speaking in primary school were: flashcards used to elicit vocabulary, listen-and-repeat activities, say and point /mark, listen point and say, chant and act, look and say.

All of these activities require either repetition or recall of single words or phrases. According to the majority of participating teachers, activities requiring semi-controlled or free and creative language use, such as role-playing, acting out or discussing ideas were not accepted as suitable until secondary school.

Data obtained from a four-year period of lesson observations in seven schools in Poland during the ELLiE study combined with data from teacher interviews in Years 1 and 4 confirm that the selection of activities used by teachers in primary classes with children aged 7 to 10 does not contain interactive oral tasks. In the Polish context, the most frequently used oral practice activities were chants and songs, chorus practice, games played with the teacher and drama (miming). Even though the learners observed were active during the lessons, they did not engage in oral interaction tasks in pairs or small groups. This observation was surprising, especially in Grade 4 when learners were ten-year-olds and their language repertoires and cognitive development should permit simple interaction practice.

\section{Language policy perspective}

Over the previous 20 years, most European Union countries have lowered the starting age for foreign language learning. In many it has been made a compulsory school subject from the onset of mandatory school education (Eurydice, 2008, 2012). National curricula for early foreign language school 
instruction that outline basic learning outcomes for this age group often make reference to the Common European Framework of Reference levels (A1-C2) (Council of Europe, 2001). It is observed that CEFR level descriptors are commonly used as a universal point of reference in school curricula, even though the document had been developed for adult professionals and did not account for the developmental characteristics of young learners. The comparison of expected learning outcomes for speaking in a foreign language at the end of primary school carried out in the ELLiE project (Enever, 2011, p. 34) shows that by the age of 10-12 years young learners are expected to reach the level of A1 (in some countries even $\mathrm{A}_{1}-\mathrm{A}_{2}$ ) and be able to engage in simple interactions and demonstrate basic communication skills.

Age-related language descriptors can also be found in the European Language Portfolio - Junior version (2006) (ELP). ELPs addressed to young learners have been published in national languages in most of the European countries (http://www.coe.int/t/dg4/education/elp/). They refer CEFR level descriptors (Council of Europe, 2001) to can-do statements formulated in terms of young learners' abilities.

Closer analysis of can-do statements concerning interaction in the foreign language in this example and in the Polish version of European Language Portfolio for 6 to 10-year-olds (Pamuła, Bajorek, Bartosz-Przybyło, \& SikoraBanasik, 2006) demonstrate that the desirable achievements at A1 level assume some basic interactive skills in answering and asking questions.

\section{Aims and research questions}

The study presented below is a sub-study of the ELLiE project and focuses on oral abilities in the fourth year of formal school instruction in one country context: Poland.

The study aimed to explore young learner performance in an interactive oral production task based on an information gap requiring A1-level language performance. Such a level of language ability is also in line with the requirements of the national curriculum. The main research question was: Can 10-year-old learners successfully complete a semi-structured task requiring asking and answering questions?

Different dimensions of oral production in oral performance of young learners were studied.

The independent variable was an interactive task that elicited language from the learners. The dependent variable was the language production operationalized as: (a) the learners' word count from the task, (b) the level of task 
achievement in asking and answering questions, as well as (c) the number of questions produced and (d) their level of elaboration. Learners' motivation for learning English and for speaking in English was identified as a contextual variable. This contextual or extraneous variable (Seliger \& Shohamy, 2000, p. 90) is an important factor that might influence the outcome of the study and is discussed in greater detail below. The study addressed the following specific questions:

- How many words will individual learners produce in the task?

- What is the level of task achievement for Part 1 when answering questions, and Part 2 of the task when the learners are asking questions?

- How many questions are asked during the task, and what is the distribution of the most elaborate questions among the learners?

- Is there a relationship between the number of words produced in the task and the learners' motivation to speak English?

\section{Method}

\section{Participants}

Participants in the study were in their fourth year of primary school and had been learning English as a compulsory school subject since Grade 1. The children selected were a convenience sample chosen from 180 young learners participating in ELLiE in Poland. Six learners from one class of each of seven schools were selected on the basis of teachers' reports to ensure equal proportions of learners with low, medium and high abilities. Schools were chosen to represent different socio-economic millieux. Classes were followed over four years and the six children chosen as the focal group were interviewed by the researcher, who asked them to perform one or two oral tests in English each year. One researcher performed all testing and interviews.

\section{Instruments and procedure for data collection}

An oral production task and a smiley questionnaire used in the ELLiE project (Enever, 2011, pp. 13-18) were used in the present study.

\section{Oral production task}

The task was designed to elicit interactional speech. The format of the task was a question-and-answer game to guess information from a picture. The children were asked to describe people, give locations and ask questions about people's appearance and location. Part One was a set of seven questions that 
allowed for responses in words, short phrases or short sentences, depending on the learners' level of language proficiency. Each question had an additional prompt when learners needed support to produce their response. The interviewer was instructed to wait for five seconds for each answer and move onto the next question. In Part Two, all learners were given a chance to take turns asking their interviewer questions and were briefly encourage to do this (Table 1).

Table 1: Oral production task description

\begin{tabular}{|l|l|}
\hline \multicolumn{2}{|l|}{ Warm-up } \\
\hline Interviewer's questions in L2: & (prompt: My name is... What's your name?) \\
\hline - What's your name? & $\begin{array}{l}\text { (prompt: This girl is 10-years-old pointing at } \\
\text { a picture. And you? How old are you?) }\end{array}$ \\
\hline - How old are you? & $\begin{array}{l}\text { (prompt: I've got one sister and no brothers, } \\
\text { and you?) }\end{array}$ \\
\hline - Have you got any brothers or sisters? & \\
\hline Guessing game & \\
\hline Part 1: answering questions & $\begin{array}{l}\text { (prompt: You are a girl. It this person a boy } \\
\text { or a girl?) }\end{array}$ \\
\hline Interviewer's instruction in L1: Choose a person in the picture and I will guess who this is. \\
\hline - Is it a boy or a girl? & $\begin{array}{l}\text { (prompt: You are 9/10 years old, how old is } \\
\text { he/she?) }\end{array}$ \\
\hline - How old is he/she? & (prompt: I'm happy...) \\
\hline - Is he/she happy or sad? & $\begin{array}{l}\text { (prompt: Is he tall or short? What colour is } \\
\text { his hair?) }\end{array}$ \\
\hline - What does s/he look like? & (prompt: I'm wearing....) \\
\hline - What is s/he wearing? & (prompt: Is he near the table?) \\
\hline - Where is s/he in the picture? & (prompt: Is he running?) \\
\hline - What is s/he doing? & \\
\hline - Would you like to be his/her friend? Why? & \\
\hline & \\
\hline Part 2: asking questions & $\begin{array}{l}\text { Interviewer's instructions in L1: Now it's my turn. I choose a person and you guess. Ask as } \\
\text { many questions in English as you can. }\end{array}$ \\
\hline
\end{tabular}

The children were tested individually; the researcher was not a stranger to the learners. She had already carried out lesson observations, testing and individual interviews with these pupils over three years. During the interview each learner was first given three short warm-up questions and was then invited to play the game in which they answered the researcher's questions and later asked her their own questions to complete the task. Their performance was audio-recorded and later transcribed. 


\section{Smiley questionnaire}

A smiley questionnaire was administered to all participants of the ELLiE project. It consisted of eight questions that referred to feelings about language classes and different types of language activities. One of the questions concerned attitudes towards speaking activities. Responses to this question were analysed in the context of language achievement in the oral production task.

\section{Analysis}

Transcribed language samples of student performance were coded and analysed to estimate the learners' fluency, task-achievement and the quality and quantity of questions. The fluency measure was later correlated with learners' motivation for speaking activities derived from the smiley questionnaire.

\section{Fluency measure}

Studies on language fluency typically focus on temporal properties of speech, such as pause frequency, duration and distribution, speech rate (i.e. the number of words per minute), or a mean length of run (Fillmore, 1979; Lennon, 2000; Kormos, 2006; Mora, 2006). The fluency measures adopted in the ELLiE study (Szpotowicz \& Lindgren, 2011, p. 128) were: (a) total number of words (Tokens), (b) number of different types of words (Types) and (c) number of nouns produced by the children in the oral tasks. They were used in a comparative study of linguistic development over three years. The total number of words produced in the task (Tokens) was used in this study as a measure of fluency to compare the number of words learners were able to produce in meaningful interaction. The number of words was counted in each participant's transcribed speech sample. Since the task was semi-structured and the turns were short, it was assumed to be an appropriate measure of fluency for these highly dysfluent non-native young learners. The task did not provide much opportunity for extended output on the learners' part, so no temporal measures were considered to be suitable.

\section{Questions - quantity and elaboration}

Questions play a vital role in communication but the tasks that are offered in lower primary language education more often assume a reactive rather than a proactive role for young learners as interlocutors. In this study, additional focus was given to questions as indicators of elaboration of language skills. Research into the development of interrogative forms in L2 (Cazden, 1975; Wode, 1978) describes the order of acquisition in which questions develop 
in L2. Some longitudinal studies (e.g. Cazden, 1972) show striking similarities between the order of interrogative forms in L1 and L2. The finding may be relevant to this study, as the learners were at the age when they are still developing their L1 repertoires. Questions asked by the learners in this study were scored on a scale of codes (1-6). The scale was created on the basis of the main stages of interrogative form development described by Ellis (1985, p. 60, 66), which was adapted after the initial analysis of the transcriptions of the speech samples. The scale extends over six categories, as follows:

1. No questions were asked

2. Words or phrases were used with rising intonation in the function of questions, e.g. Short? Red?

3. Affirmative sentence was used with rising intonation, e.g. He's sitting?

4. The interrogative element (wh-, do-, etc.) was fronted, there was no subject-verb inversion and the auxiliary was missing, e.g. What he wearing? Where he in the picture?

5. Inversion in wh-questions and in yes/no questions was used correctly, e.g. Is she reading? What colour is her hair?

6. Embedded questions, negative questions and question tags were used.

The responses never contained structures that would have been described by Category 6 .

All questions in the transcribed samples from Part 2 of the game (asking questions) were evaluated and labelled using the above codes. The number of questions used and the most elaborate type per student are reported below.

\section{Task-achievement measure}

To determine whether the communicative goal was successfully achieved by the participants, it was necessary to develop a scale for evaluating the task (Luoma, 2004, p.187). For Part 1, the task was to answer questions to enable the interviewer to guess the identity of the person in the picture, and for Part 2 to ask a sufficient number of questions to identify the person the interviewer had in mind. After the initial analysis of several transcripts, the following scales were developed in the ELLiE team and adapted for this study.

Task-achievement scale for oral production:

1. No production in L2 or a single attempt irrelevant for completing the task;

2. Partially completed with substantial self-help using L1 or having minimal ability;

3. Completed with some self-help using L1 or having limited ability;

4. Fully completed and showing some elaboration. 


\section{Relationship between fluency and motivation for speaking}

Positive attitudes to learning foreign languages in primary school in different countries and cultures have been reported by many studies (Burstall, 1975; Nikolov, 1999; Donato, Tucker, Wudthayagorn, \& Igarashi, 2002; Butler, 2009). The ELLiE project confirmed children's positive feelings about learning a foreign language in the first years of primary school across seven countries. Further analyses also demonstrated that children with positive attitudes displayed higher levels of lexical diversity in the oral production task (Mihaljevic Djigunovic \& Lopriore, 2011, p. 52).

This study investigated the relationship between the participants' feelings about speaking English and the amount of language they produced measured in this study. Learners completed a smiley questionnaire containing questions about their feelings concerning the use of the four language skills and the types of activities in their language classes. Answers were marked on a smiley scale and the questions were presented in the learners' L1. The question used for analysis was 'How do you feel about speaking activities this year?'

\begin{tabular}{|c|c|c|c|c|}
\hline$: 0$ & $:$ & $\oplus$ & $\oplus$ & $+:)$ \\
\hline dislike a lot & dislike & $\begin{array}{c}\text { neither like } \\
\text { nor dislike }\end{array}$ & like & like a lot \\
\hline
\end{tabular}

The relationships between answers and the measure of fluency were analysed and are reported in the Results section below.

\section{Results}

\section{Fluency}

The distribution of the total number of words produced in the oral task is presented in Figure 1. The most frequent number was around 20 words and only five learners demonstrated more than 45 words. The highest score was 96 words and was achieved by one child. One child made no spoken response throughout the interview. 


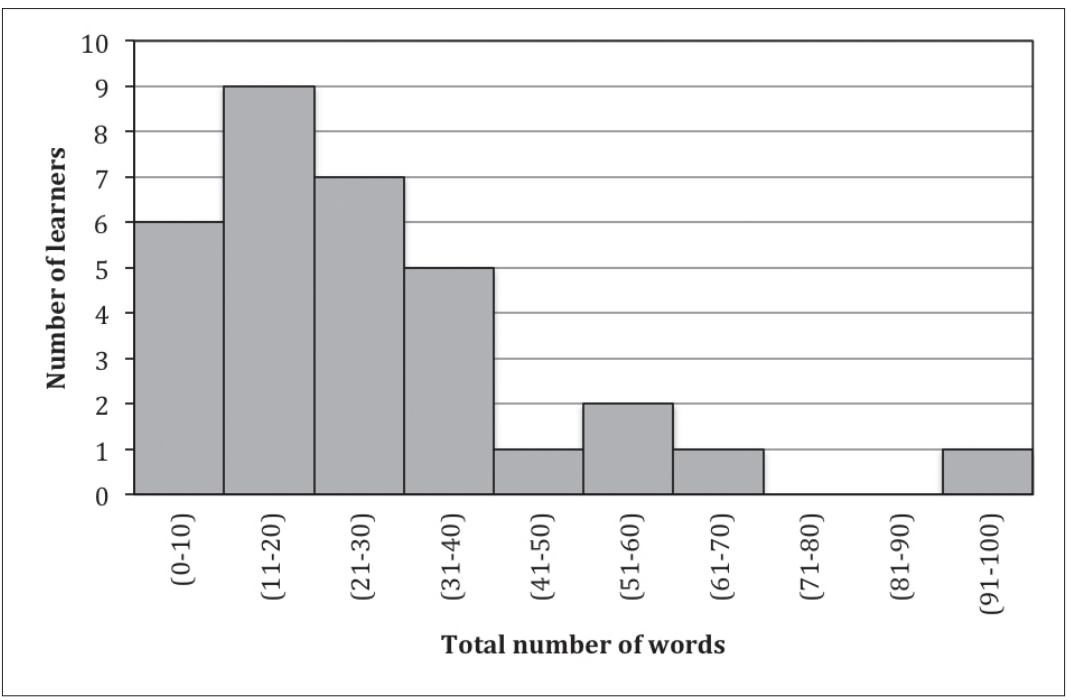

Figure 1: Distribution of the total number of words produced by participants in the oral task

This measure of quantity shows that after the first four years of school there is already great variation in the productive ability of young learners. Taking into account the fact that learners selected for the study were of low, medium and high language ability, it may represent a larger population of Polish learners.

\section{Task achievement}

Task achievement was rated separately for Part 1 and Part 2. In each of the parts, the learner had a different role to play and these roles assumed the use of different language structures: affirmative in Part 1 and interrogative in Part 2. The first part of the interview, when the participants responded to questions asked by the interviewer, provided a more secure environment when one-word or phrase utterance allowed for completing the task successfully. The role of the respondent in the interaction is typical for young learners who frequently answer questions individually and chorally in the classroom. The sample participating in the study performed relatively well in Part 1 . The results of their speech sample rating are presented in the first graph of Figure 2. Half of the learners completed the task without difficulty and 15\% (6 learners) demonstrated some elaboration, which included answers with full sentences and relatively complex structures with no L1 support in their performance. The remaining $35 \%$ (14 learners) demonstrated minimal production or used their mother tongue to make themselves understood, but the additional qualitative 
observation showed that the learners would more often use very simple, oneword responses than their L1. In the other half of the sample, $42 \%$ (17 learners) experienced some difficulty in completing the task but only $8 \%$ (3 learners) did not answer any questions. Any explanation that the task was unclear to participants can be eliminated since it was explained in their L1 and they proved that they had understood the task by selecting a person in the picture.

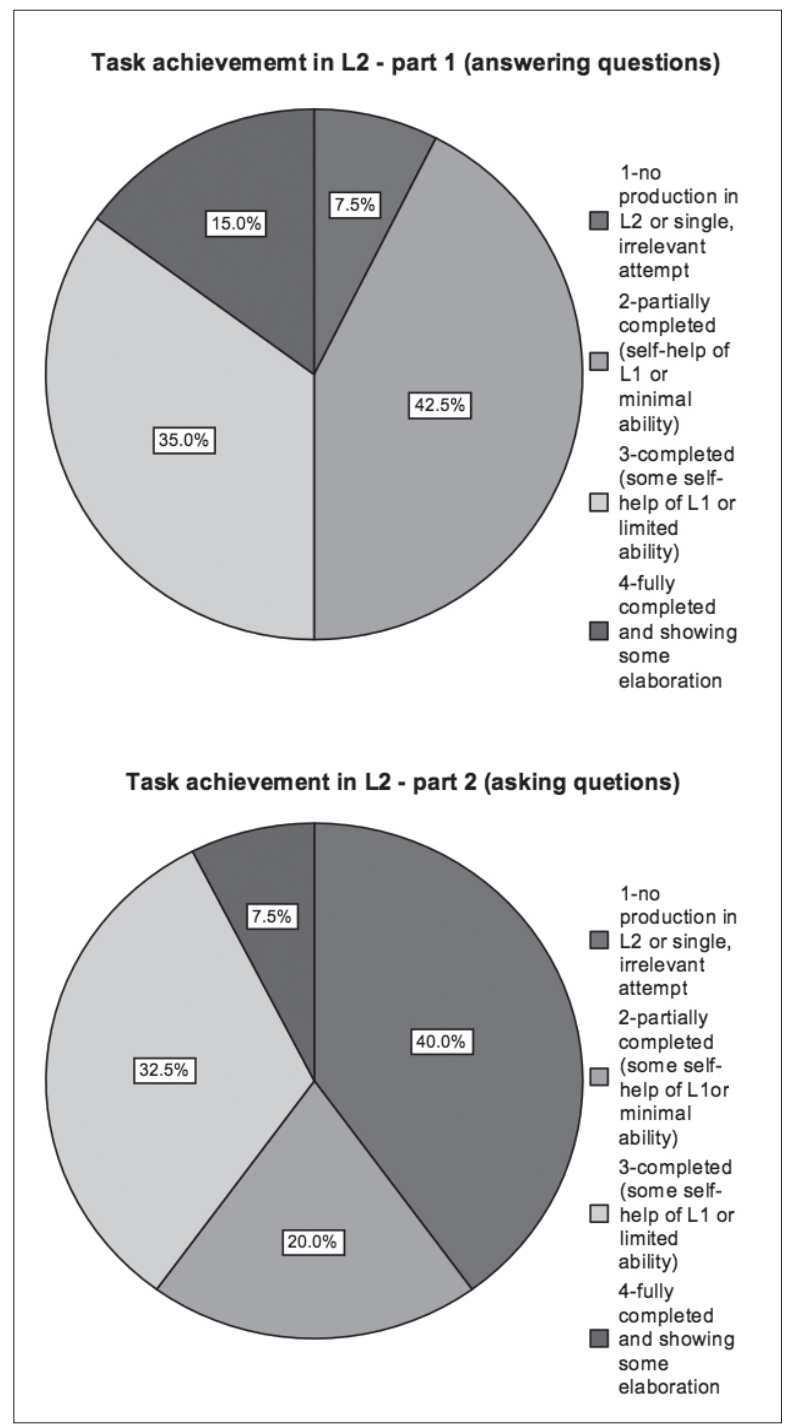

Figure 2: Distribution of learners whose task achievement was rated on a scale from 1 (no L2 produced) to 4 (fully completed) 
The results for Part 2 of the game, in which learners were invited to take the initiative to ask their own questions in order to discover which child in the picture had been chosen by the interviewer, are shown in the second graph in Figure 2. Although similar questions had been asked by the interviewer in Part 1 , setting useful examples of performance, the majority of learners had evident difficulty performing the task.

The most striking difference in results is that $40 \%$ (16 learners) did not produce any L2 and stopped trying even if they had made some initial attempt, often commenting that this part was too difficult. Only $8 \%$ (3 learners) demonstrated a high level of achievement and some elaboration; their questions were complete and usually grammatically correct.

In summary, in all the four categories the results were lower for asking questions than for answering them. For 19 students, the score was lower in Part 2, and for another 19 it was in the same category as in Part 1; however, this group also included the category of zero production in both parts.

Only two learners in the sample scored differently from the rest. Their level of task achievement improved from Category 2 (partially completed with substantial help or showing minimal ability) to Category 3 (completed with some help of L1 or showing limited ability). In the qualitative analysis of their transcribed speech samples, the two learners were more active in Part 2 and asked a number of questions to achieve the task. They were either risk-avoiding types of learners, who needed to gain confidence to fully participate, or remembered the questions from Part 1 and felt secure using them when they were still in their memory. The qualitative analysis of the two cases encouraged further quantitative investigation of questions in the transcribed samples.

\section{Questions}

In Part 2 of the game, learners asked varying numbers of questions in order to establish which picture the interviewer had selected. Participants applied different communicative strategies to complete the task, which depended not only on language ability but also on their internal motivation to satisfy their curiosity. Although the interviewer's aim was to elicit no fewer than three questions, the number of questions asked varied widely (see Figure 3). 


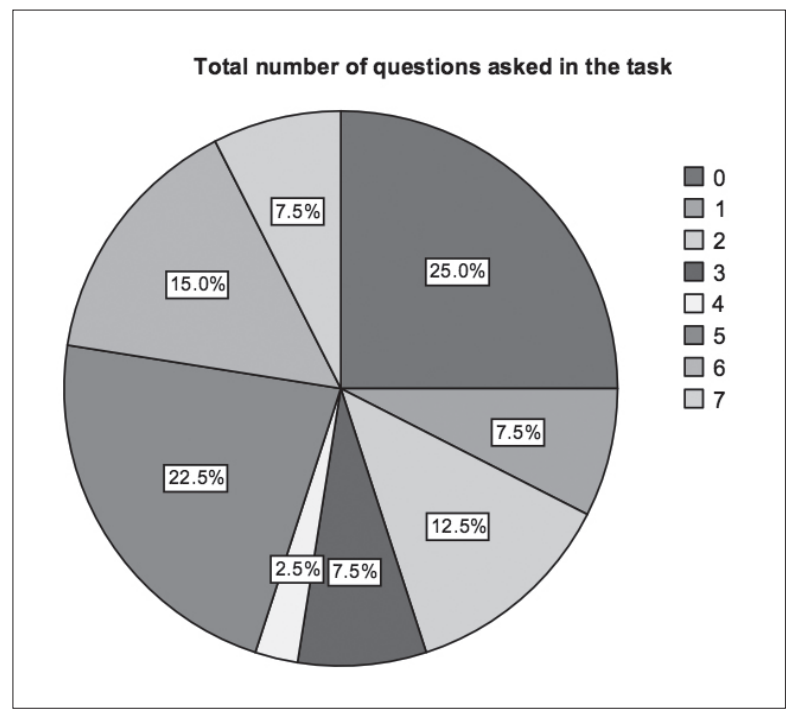

Figure 3: Distribution of children who produced different number of questions in Part 2 of the game

One child in four did not attempt to ask any questions and 8\% (3 children) made some initial attempt, repeating one of the interviewer's questions.

The learners who were more active interlocutors and asked more questions were also more successful in completing the task. There was a significant relationship between the number of questions asked and performance on the task: $\mathrm{r}=0.86, \mathrm{p}<0.001$.

The qualitative analysis showed that regardless of their number, the questions produced were at different levels of complexity, ranging from simple words with rising intonation to full, grammatically correct questions. Questions in speech samples were evaluated according to the level of linguistic complexity. The results in Figure 4 display distribution of the most elaborate question asked by each participant. 


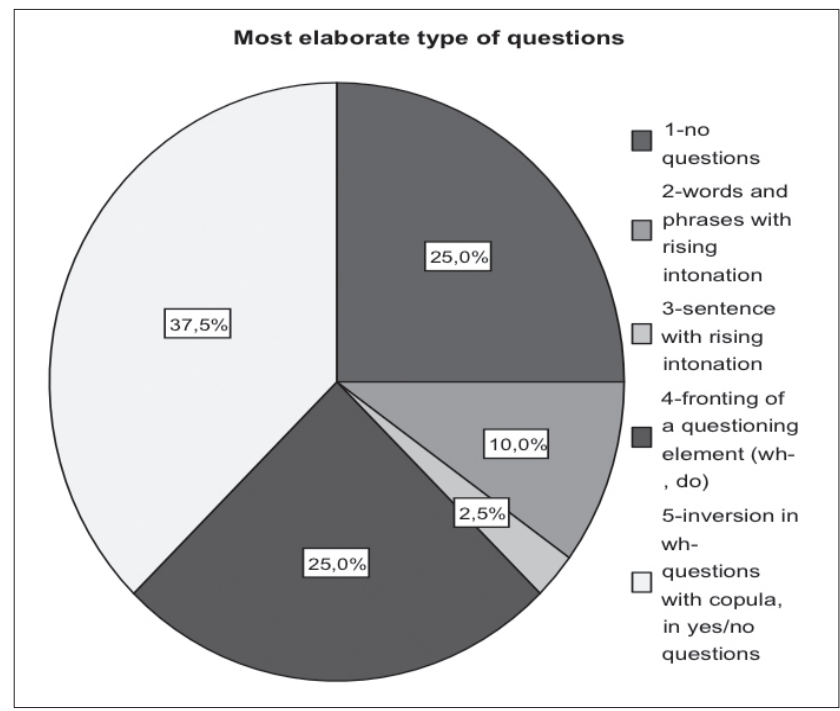

Figure 4: Distribution of most elaborate questions each child produced

Ignoring children who did not attempt the tasks, the remaining participants were able most frequently to form fully-developed questions beginning with question words and employing correct inversion to elicit yes/no answers. Twenty-five per cent were able to form a question but failed to produce the correct inversion. Whilst this breakdown only shows the production of the most elaborate forms, the proportions are consistent with quantitative results (number of questions).

The level of elaboration of questions was positively related to the number of questions asked by the learners $(\mathrm{r}=0.69, \mathrm{p}<0.001)$. The correlation is quite strong and significant, indicating that more elaborate question use was usually connected with a higher number of questions asked.

\section{Motivation and attitudes to speaking}

Learners' attitudes to speaking were investigated by means of a smiley questionnaire in which the participants marked smiley icons that represented their feelings. The question about speaking was: 'How do you feel about speaking activities this year?' The results for the whole sample of Polish learners are presented in Figure 5. The attitude to speaking activities was predominantly positive or very positive. The happy smiley (Category 4) was selected by $43 \%$ and the very happy smiley (Category 5) by $23 \%$ of all learners. Only $11 \%$ had negative or very negative feelings about speaking activities in class (Categories 1 and 2 ). 


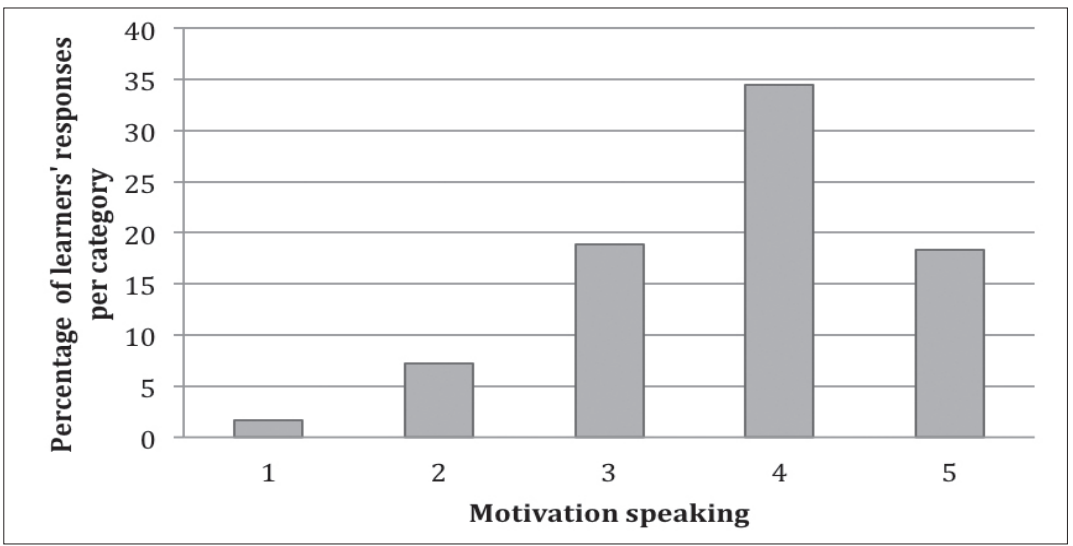

Figure 5: Distribution of responses to the question about attitude to speaking activities in a smiley questionnaire (from 1 - very negative to 5 - very positive)

There was a statistically significant difference in the mean of the total number of words produced in the oral task between the groups of learners who had different attitudes to speaking activities $(F(4.34)=9.03 ; p<0.001)$. The Bonfferoni post-hoc test indicated that there was a significant difference in the total number of words between the group with the highest motivation (5) and the three groups of learners with low motivation: Group 1 ( $\mathrm{p}<0.005)$, Group 3 ( $\mathrm{p}<0.001)$ and Group 4 ( $\mathrm{p}<0.05)$. It means that children with positive feelings about speaking tasks were significantly more fluent than children who expressed strongly negative feelings (see Figure 6). Children who produced the longest samples of speech were those who liked speaking activities the most.

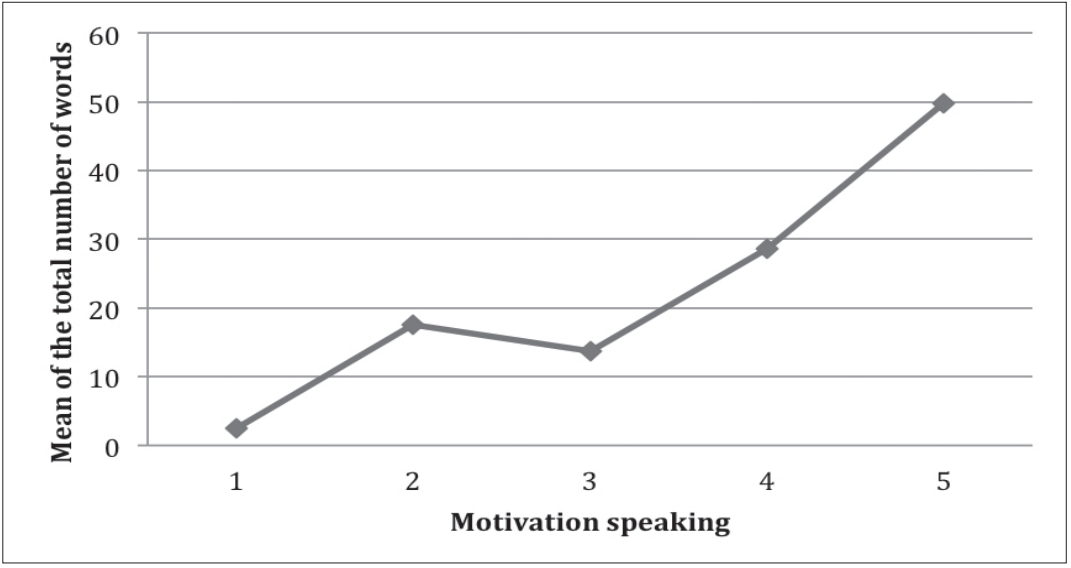

Figure 6: Group means for the number of words on the basis of answers in the smiley questionnaire. 
Figure 6 presents the mean values of the total number of words produced by the learners who declared their feelings about speaking tasks on the smiley scale.

\section{Discussion}

The research question was to establish whether ten-year-old learners are ready to usefully employ basic communicative abilities in the classroom. Could they successfully complete a semi-structured task which required asking and answering questions? More specific questions were posed about measures of fluency, task-achievement and the development of questions. The research question was framed in the context of curricular requirements which broadly refer to A1 CEFR level descriptors, which indicate the use of basic communicative language ability to ask and answer simple questions. Additionally, productive speaking ability was related to the learners' motivation for speaking activities to determine the impact of positive attitudes on young learners' language production. It was observed that the learners produced variable numbers of words in the task. Further contextual exploration revealed that the learners with the highest number of words in the task participated in additional language courses and were offered extensive language learning support from their parents. All five of the learners whose score exceeded 45 words received extra tuition and enjoyed a supportive home environment.

The ability to answer questions in the interactive task shows that learners have reached the curricular requirement to answer simple questions that have been learnt in the classroom. However, the same may not be argued for their ability to ask questions. The most important finding here was that $40 \%$ of the group did not attempt the task and evaluated this part as too demanding. From the perspective of task achievement, it may be argued that this group of learners are approaching A1 but not achieving it.

Results relevant to the quantity and quality of interrogative forms used by the learners give a better insight into their learning processes. It is confirmed that learning is in progress, at different stages of development for different learners, which lends support to the view that the learners are approaching the achievement of A1 demands.

These results show that the majority of learners had acquired some form of interrogative skills although many had not fully mastered the structures and did not apply the correct subject-verb inversion. Taking into account the early age of learners and the form of their foreign language instruction (without explicit grammar presentation) it might be assumed that some questions were 
acquired as formulaic chunks and their recall had been reinforced through the presentation in Part 1 . This suggests that participants did not demonstrate their explicit language knowledge about question formation, but were simply repeating memorized chunks of language.

The level of elaboration of questions was less strongly, although still positively, related to the number of questions asked by the learners $(r=.69$, $\mathrm{p}<.001)$ than the task achievement in Part 2 and the number of questions $(\mathrm{r}=.86, \mathrm{p}<.001)$. This lower correlation may have been influenced by four of the low-ability participants, who adopted a risk-taking strategy and performed successfully with very limited language means and very basic question forms. One such example is presented below:

Learner A - Game part 2

S: $\quad$ hmm @p how ol...nie @pl (no) \# boy and girl?

Inv: Boy.

S: Wearing t-shirt?

Inv: Yes.

S: Yellow t-shirt?

Inv: No.

S: Green t-shirt?

Inv: No.

S: White t-shirt?

Inv: No.

S: hmm @p what colour hair?

Inv: Red, red hair.

S: hmm@p black trousers?

Inv: Yes.

/the child is showing a person in the picture/

Qualitative analysis of the samples revealed that some learners, who can be considered 'risk-avoiders', improved their performance in Part 2 of the game. This may be explained by their feeling more secure with the second task or having observed (and learnt from) the way the interviewer asked her questions in Part 1. One such example is presented below:

Learner B - Game part 1 and 2

Part 1

Inv: Is it a boy or a girl?

S: Boy.

Inv: How old is he?

$\mathrm{S}$ : hmm @p he is xx hmm@p eight years old? 
Inv: Is he happy or sad?

S: \# nie wiem, czy on jest taki poważny @pl (I don’t know if he is that serious)

Inv: What does he look like?

S: \#hehmm@p

Inv: Is he tall or short?

S: $\quad$ Short.

Inv: What colour is his hair?

S: $\quad$ \# fair, he's fair

Inv: What is he wearing?

S: \#\#

Inv: I'm wearing a blue and black jumper and what is he wearing? What is the boy wearing?

S: Blue@c.

Inv: Blue trousers?

S: Jeans. And... bluzka jak jest @pl (how to say t-hirt)

Inv: T-shirt.

S: Blue t-shirt.

Inv: Where is he in the picture? [/]

S: $\quad$ The boy \# obok to jest @pl (how to say near?).

Inv: Is he near the table?

S: Nie, jak jest, że przy @pl (no, how is near).

Inv: Near.

S: Aha, nearhmm@p@c.

Inv: Board?

S: Board!

Inv: What is he doing?

S: \# he hmm@p writing.

Inv: Writing or reading?

S: $\quad$ Writing.. że czyta @pl (that he’s reading)

Inv: Aha, so reading.

S: Reading.

Inv: Is it this boy?

S: Yes.

Part 2

$\mathrm{S}: \quad$ Is boy?

Inv: Yes, it's a boy.

S: He's short? 
Inv: No, tall.

S: He's blond hair?

Inv: No, red hair.

S: $\quad$ hmm@p is \# blue shirt?

Inv: Yes, blue shirt.

S: Ten@pl (this one). /pointing to the picture/

Inv: Jeszcze jedno pytanie zadaj. @pl (Ask me one more question)

S: He black [/] trousers?

Inv: Yes, yes, it's that boy.

Symbols in the transcription:

hmm@p - filled pause, [/] - repetition, @pl - Polish words, \# - very short pause, \#\# - longer pause, @c - invented word, $\mathrm{xx}$ - unidentifiable material

Another observation about the performance of Learner B here is that the child was negotiating meaning with the interlocutor, and employed L1 in an attempt to be as accurate as possible. This shows that some children at this age are able and willing to negotiate meaning to facilitate communication. As argued by Pinter (2006), this ability is slowly developing in young learners.

The analysis of interrogative forms used by children in this study raises a question about the stage of development of their interrogative forms in L1. Would their questions, if asked in L1, differ much in elaboration? Would they provide full questions or would they be happy with simple phrases with rising intonation? Their output would be grammatically accurate in L1 at this age but might consist of short question forms, rather than full questions, even though more elaborate forms are familiar at this age. Such verbal behaviour might then be attributed to learners' lack of awareness of the interviewer's expectations to hear more rather than less elaborate responses. Using Bachman and Palmer's (2010) model of communicative language ability, it would indicate that their pragmatic knowledge and strategic competence are still not fully developed. It should be considered that children's language production in L1 might not reveal their highest level of ability, unless they are specifically prompted. Awareness of the expected register may also be connected with personality traits and general communicative ability of a person. More extraverted and field-dependent learners might make more effort to participate. It was already observed in the interviews that some children resorted to the simplest means to establish communication while others refused to participate at the first instance of experiencing difficulty. It may be assumed that reluctance to participate indicated lack of ability but it also seemed that in several cases the reason might have been with 
their personality and learner style. The implication for further studies is that L1 communicative ability, personality, and use of strategies should be further explored to show their potential influence on learner productive skills in L2.

In answer to the last question about the relationship of attitude and productive ability, the correlational analysis showed that the learners who liked speaking activities were ready to produce more words and thus engaged more extensively in the task. A possible explanation for this result is that positive classroom experience with speaking activities stimulates language production, or that it is positive because the learners already possess higher language ability, which they demonstrate with ease in the classroom and in interactive tasks. Further exploratory research is necessary to recognize the factors which condition children's attitudes and achievement.

\section{Conclusions}

In conclusion, fewer than half of the participants reached the A1 level (CEFR) in asking and answering simple questions to the requirements of the curriculum. Participants below the A1 level were generally approaching it at least in their ability to answer questions. Further research is needed to develop common age-appropriate level descriptors for learners who are at this stage at primary school. Pioneering work on slightly older learners, addressing language achievements in reading and writing has been documented in the AYLLIT project (Assessment of Young Learner Literacy Linked to the CEFR) (Hasselgreen et al., 2011). This work could be an important point of reference in establishing level descriptors for young learners' oral skills.

Analyses of language samples produced by the learners gave insight into their stage of linguistic development. Using Bachman and Palmer's (2010) framework of communicative language ability, it was possible to observe instances of grammatical knowledge demonstrated in varied stages of linguistic elaboration in questions. The emerging strategic competence could be seen in the qualitative analysis of the speech samples and showed instances of planning (e.g. selecting the element of language to be used) and goal setting (e.g. deciding not to continue with the task).

The children were interested and motivated to take part in interactive speaking activities, which was demonstrated in the interviews and in the analysis of their responses to the smiley questionnaire. The study showed that the majority of children were ready for the challenge of individual oral production both linguistically and emotionally, which implies that more activities of this type should be introduced in the language classroom. Children who are eager 
to work in pairs and interact should be introduced to more of these activities at an earlier age (Szpotowicz \& Szulc-Kurpaska, 2009). Games stimulating communication, in which information is exchanged to reach a stated goal and accomplish a task, provide positive motivation for speaking and elicit language output. Such games may serve as useful instruments for teachers in assessing young learners' communication abilities in the classroom. The positive attitude to the interactive task and the effort made in contributing to the performance with the interviewer draw attention to the importance of task-appropriateness and usefulness.

Analysis of questions produced by children suggests that they use language as formulaic chunks learnt as unanalysed sets of words and repeat readymade formulas which, to their mind, fit the context. This observation implies that more formulaic input should be provided in the young learner classrooms to supply teaching focused on semantic lexical sets which dominated in the classes of the Polish ELLiE sample. It seems that teacher's consistent use of increasingly more elaborate classroom language, the use of stories and providing stimulating and meaningful language practice should provide L2 input rich in formulaic language and effectively support children's oral skills (Cameron, 2001).

Once again, motivation appeared to be an important factor in language learning and showed that children who enjoyed speaking activities produced more language than children who had negative feelings about speaking in the classroom. Better insight into motivation and language development of young learners is necessary and should result in more effective and challenging stimulus in the classroom. Perhaps more detailed clarification of the curriculum stating clearer lexical and structural goals could improve the uptake and implementation of strategies to stimulate oral abilities and boost motivation.

The study had some limitations as the tasks involved learners who had had little prior experience with these types of tasks. Had the structures been more frequently activated in the classroom, the participants might have produced more elaborate and extensive output. The element of novelty has to be taken into account when considering the results. The participants of this study were selected from a convenience sample of learners, so the results can only indicate possible directions for further studies on a representative sample of Polish learners and do not allow conclusions for the whole population of Polish learners. Learner strategies which were mentioned in the analysis of speech samples deserve a more thorough investigation in another study.

While general insight from the results is valuable, descriptive and informative for educational policy, it may be misleading to interpret inter-individual scores beyond class level. It would be ill-advised to use this work as 
an argument for mandatory state-approved testing. Further studies, including experimental studies into foreign language teaching practice are necessary to draw realistic and challenging objectives for learners who are at the age of continuous cognitive, social and emotional growth and change.

\section{Acknowledgements}

The author would like to thank Professor Carmen Muñoz of the University of Barcelona for suggesting the task achievement measures in the ELLiE project, which were further adapted and used in this study. Special thanks to Dorota Campfield, Ph.D., of the Educational Research Institute in Warsaw and Patrick Fox for their valuable comments on earlier drafts of this text. I would also like to express my appreciation to Ludmiła Rycielska for her help with the preparation of this article.

\section{References}

Bachman, L. F, \& Palmer, A. (2010). Language Assessment in Practice. Oxford: Oxford University Press.

Brewster, J., Ellis, G., \& Girard, D. (2002). The Primary English Teacher's Guide. New Edition. Harlow: Pearson Education.

Burstall, C. (1975). Primary French in the balance. Foreign Language Annals, 10(3), 245-252.

Butler, Y. G. (2009). Issues in the assessment and evaluation of English language education at the elementary school level: Implications for policies in South Korea, Taiwan, and Japan. The Journal of Asia TEFL, 6(2), 1-31.

Cameron, L. (2001). Teaching Languages to Young Learners. Cambridge: Cambridge University Press.

Cazden, C. (1972). Child Language and Education. New York: Rinehart \& Winston.

Cazden, C., Cancino, H., Rosansky, E., \& Schuman, J. (1975). Second Language Acquisition Sequences in Children, Adolescents and Adults. Final Report, US Department of Health, Education and Welfare. CILT (2006). European Language Portfolio - Junior version. Retrieved 12.6.2012 from www.cilt.org. uk/primary.aspx

Council of Europe. (2001). Common European Framework of Reference for Languages: Learning, teaching, assessment. Cambridge: Cambridge University Press.

Donato, R., Tucker, G. R., Wudthayagorn, J., \& Igarashi, K. (2002). Converging evidence: Attitudes, achievements and instruction in the later years of FLES. Foreign Language Annals, 33(4), 377-393.

Dulay, H., \& Burt, M. (1974). Natural sequences in child language acquisition. Language Learning, 24, $37-53$.

Ellis, R. (1985). Understanding Second Language Acquisition. Oxford: Oxford University Press. Enever, J. (2011). Policy. In Enever, J. (Ed.), ELLiE. Early Language Learning in Europe (pp. 23-42). 
London UK: British Council. Retreived form http://www.teachingenglish.org.uk/publications/early-

language-learning-europe

Fillmore, C. J. (1979). On fluency. In D. Kempler, \& W. S. Y. Wang (Eds.), Individual Differences in

Language Ability and Language Behavior (pp. 85-102). New York: Academic Press.

Hasselgreen, A., Kaledaite, V., Maldonado Martín, N., \& Pižorn, K. (2011). Assessment of Young

Learner Literacy, linked to the Common European Framework of Reference for Languages. European

Centre of Modern Languages/ Council of Europe. Retreived from http://book.coe.int

Key Data on Teaching Languages at School in Europe (2008). Brussels: Eurydice.

Key Data on Teaching Languages at School in Europe (2012). Brussels: Eurydice.

Kormos, J. (2006). Speech Production and Second Language Acquisition. Mahwah, New Jersey/

London: Lawrence Earlbaum Associates, Publishers.

Lindgren, E., \& Muñoz, C. (2012). The influence of exposure, parents, and linguistic distance on young European learners' foreign language comprehension. International Journal of Multilingualism,

pp. 1-25. Retreived form http://dx.doi.org/10.1080/14790718.2012.679275

Luoma, S. (2004). Assessing Speaking. Cambridge: Cambridge University Press.

McKay, P. (2006). Assessing Young Language Learners. Cambridge: Cambridge University Press.

Mihaljevic Djigunovic, J., \& Lopriore, L. (2011). The learner: do individual differences matter? In J.

Enever (Ed.), ELLiE. Early Language Learning in Europe (pp. 43-6o). London UK: British Council.

Mora, J. (2006). Age effects on oral fluency development. In C. Muñoz (Ed.), Age and the Rate of

Foreign Language Learning (pp. 65-88). Clevedon, Buffalo, Toronto: Multilingual Matters.

Muñoz, C. (2007). Age-related differences and second language learning practice. In R. M. DeKeyser, Practice in a Second Language. Perspectives from Applied Linguistics and Cognitive Psychology (pp.

229-255). New York: Cambridge University Press.

Nikolov, M. (1999). 'Why do you learn English?' 'Because the teacher is short'. A study of Hungarian children's foreign language learning motivation. Language Teaching Research, 3(1), 33-56.

Pamuła, M., Bajorek, A., Bartosz-Przybyło, I., \& Sikora-Banasik, D. (2006). Europejskie portfolio językowe dla dzieci od 6 do 10 lat. Warszawa: Centralny Ośrodek Doskonalenia Nauczycieli.

Pinter, A. (2006). Teaching Young Language Learners. Oxford: Oxford University Press.

Seliger, H. W., \& Shohamy, E. (2000). Second Language Research Methods. Oxford: Oxford University Press.

Slattery, M., \& Willis, J. (2001). English for Primary Teachers - A handbook of activities and classroom language. Oxford: Oxford University Press.

Szpotowicz, M., \& Szulc-Kurpaska, M. (2009). Teaching English to Young Learners. Warszawa: Wydawnictwo Szkolne PWN.

Szpotowicz, M., \& Lindgren, E. (2011). Language achievements: a longitudinal perspective. In J. Enever (Ed.), ELLiE. Early Language Learning in Europe (pp.125-143). London UK: British Council. Wode, H. (1978). The L1 vs. L2 acquisition of English interrogation. Working Papers on Bilingualism, 


\section{Biographical note}

Magdalena Szpotowicz, dr., University of Warsaw, Poland, Graduate of the Institute of English at the University of Warsaw. Assistant Professor at the Faculty of Education of her alma mater. She also works at the Educational Research Institute in Warsaw where she is involved in a national research project devoted to the monitoring of pupils' FL achievement in school education. In the years 2006-2010 a country manager of a multinational longitudinal research study Early Language Learning in Europe (ELLiE). Coauthor of the Polish national curriculum for foreign languages and author of coursebooks, school curricula and didactic materials. 